\title{
Postharvest Handling Of Coffee In Small Medium Enterprises (SMEs) Tugu Juang Coffee, Pulosari Village, Pemalang Regency
}

\author{
Sari Salsabila Rizkiyani* and Yan El Rizal Unzilatirrizqi \\ Program Studi Ilmu dan Teknologi Pangan, Fakultas Sains dan teknologi, Universitas Muhadi Setiabudi \\ Brebes \\ e-mail:*sarisalsabilarizkiyani@gmail.com,yan.el.rizal@umus.ac.id
}

\begin{abstract}
This study aims to determine the entire postharvest processing of coffee at Small Medium Enterprises (SMEs) Tugu Juang Coffee in Pulosari Village, Pulosari District, Pemalang Regency. The types of coffee that are cultivated and processed are robusta and arabica coffee. The research method used is observation, interview, and documentation study. The coffee processing process at Small Medium Enterprises (SMEs) Tugu Juang Coffeeis the dry (natural) processing process that starts from picking, sorting the coffee fruit, drying, peeling dry skin, roasting, resting, pulping and packaging. The water content before drying reaches $25-30 \%$ and after drying it produces a maximum moisture content of $12 \%$. The warehousing process at Small Medium Enterprises (SMEs) Tugu Juang Coffee always maintains clean sacks, ventilation and labeling.

Keywords : Coffee; SMEs; Pulosari; postharvest; processing
\end{abstract}

\section{Introduction}

Coffee Is a commodity that has been cultivated by many countries including Indonesia, and is a leading export commodity because it has a relatively high economic value in the world market [1]. Coffee is a plantation commodity that is included in the strategic commodity category in Indonesia. Indonesia is the world's fourth-largest coffee exporter with a market share of around $11 \%$ in the world [2]. Demand for Indonesian coffee has increased from time to time, such as robusta coffee and arabica coffee because it has a unique and exquisite taste (aroma, flavour) [3].

Two types of coffee develop in Indonesia, namely Arabica coffee and Robusta coffee. Most of the coffee plants come from smallholder plantations. Each coffee has its advantages, Arabica coffee has a distinctive taste so that it has a special market, while Robusta coffee is a commodity that has strategic value in the framework of empowering the people's economy. The prospect of Indonesia's coffee commodity is very large because it is supported by the availability of land for coffee development[4], and Indonesia has geographical and climate advantages that produce coffee that has a taste and aroma that is favored by the world community [5].

The principle of processing coffee cherries consists of 2 ways, namely wet processing and dry processing. In wet coffee processing with water for peeling and washing the coffee cherries, while dry processing after harvesting the coffee cherries are directly dried, the peeling of the pulp, horn skin, and epidermis is done after drying [6].

In general, there are 2 ways of processing primary coffee beans, namely wet management and dry management. Wet coffee management includes harvesting, sorting, pulping, fermentation, washing, drying, hulling, and drying rice coffee [7]. Dry or natural coffee processing, namely after the picking process of ripe coffee cherries and then drying them immediately, the peeling of the fruit skin, horn skin, and epidermis is done after the drying process [8]. At the dry coffee processing stage, it is longer than the wet method, which is 2-3 weeks [9].

Pulosari village is a district that has the highest altitude in Pemalang Regency, which is \pm 914 masl. In arabica coffee, the planting height of arabica coffee is 700-1700 masl, while robusta coffee can grow below 700 meters above sea level. This shows that Pulosari District has met the 
criteria for planting both arabica coffee and robusta coffee by local farmers. The farmers formed a business unit called the Small Medium Enterprises (SMEs) Tugu Juang Coffee which collects the coffee harvest in the Pulosari area. Coffee business can be a morning business opportunity for beginners in Pemalang Regency [10].

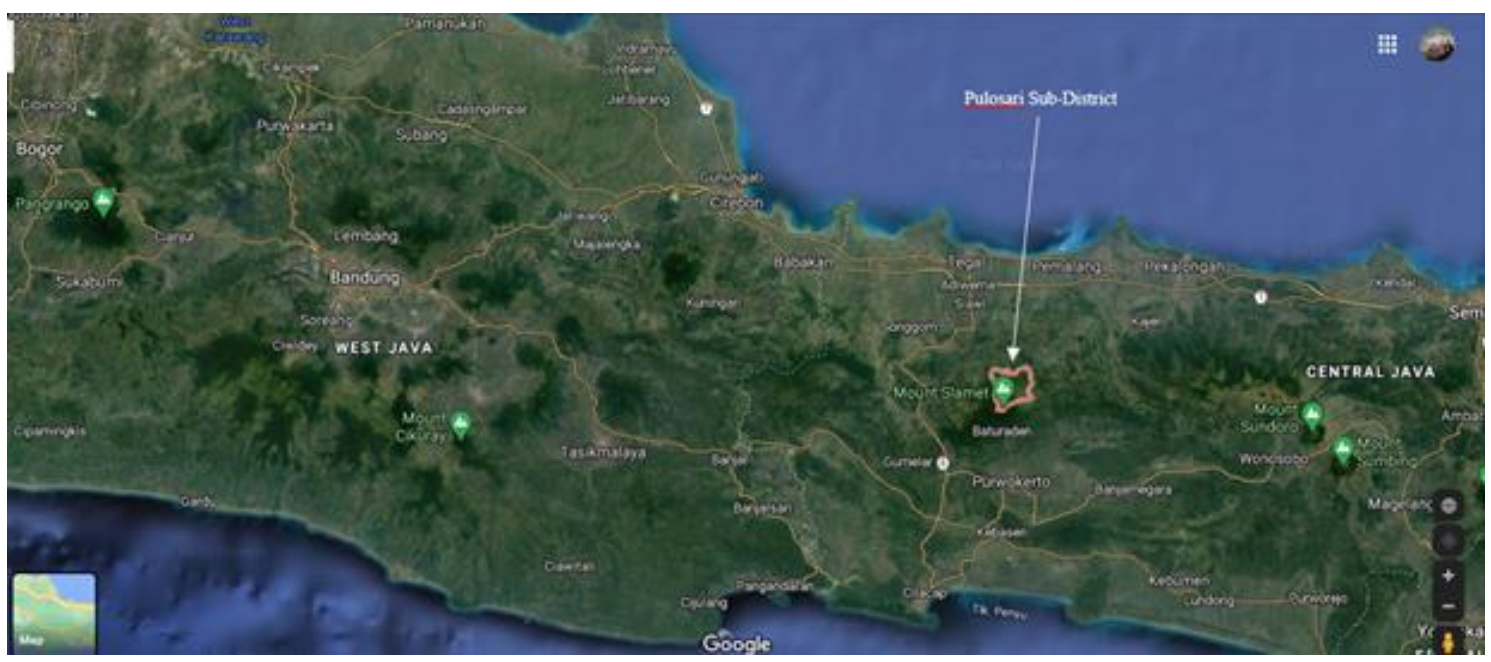

Figure 1. Location Map of Pulosari District

\section{Research Methods}

This research was carried out in September 2020, which took place at the Small Medium Enterprises (SMEs) Tugu Juang Coffee in Pulosari Village, Pulosari District, Pemalang Regency, Central Java Province. The research was initiated from the initial study for problem identification, data collection, data processing, and data interpretation. The research location was selected by a purposive method, namely deliberate selection [11].

Data collection techniques in qualitative research are by making observations, interviews, and documentation studies. The observations carried out in this study are observations. Observations were made by participant observation of the process of activities at Small Medium Enterprises (SMEs) Tugu Juang Coffee. Interviews were conducted to find out to complete data and efforts to obtain accurate data and appropriate data sources. In this study, the authors interviewed owners and their workers as informants. Documentation study in this research is needed to sharpen research analysis related to the coffee processing process at Small Medium Enterprises (SMEs) Tugu Juang Coffee.

\section{Discussion}

\subsection{Postharvest Handling}

Postharvest coffee handling at Small Medium Enterprises (SMEs) Tugu Juang Coffee is carried out using a dry process (natural). Dry processing is carried out after the coffee is harvested immediately drying (peeling the pulp, horn skin and epidermis are done after drying). Coffee is said to be dry when you stir it when hear a rustling sound. Drying can be done manually or with a dryer [12]. Drying is done in sunny weather until it gets 11-12\% moisture content. Drying takes 2-3 weeks by drying [13]. At the beginning of drying, the coffee cherries that are still wet must be turned frequently with a rake. Types of micro-organisms that can develop on the skin of the fruit, especially fungi (Fusarium sp., Colletotricum coffeanum), on the surface of the fruit that is too dry are Aspergillus niger, Penicillium sp., And Rhizopus sp. Drying with a dryer is carried out when it rains frequently [14]. Peeling the fruit skin in the dry method aims to separate the coffee 
beans from the fruit skin, horn skin, and epidermis. Peeling the fruit skin using a peeler (huller). Peeling the skin by pounding it is not recommended because it causes many seeds to break. The results of the stripping will be obtained from rice coffee beans, which are ready for storage or further processing [15].

The natural handling of post-harvest coffee at Small Medium Enterprises (SMEs) Tugu Juang Coffee is illustrated in the flow diagram below:

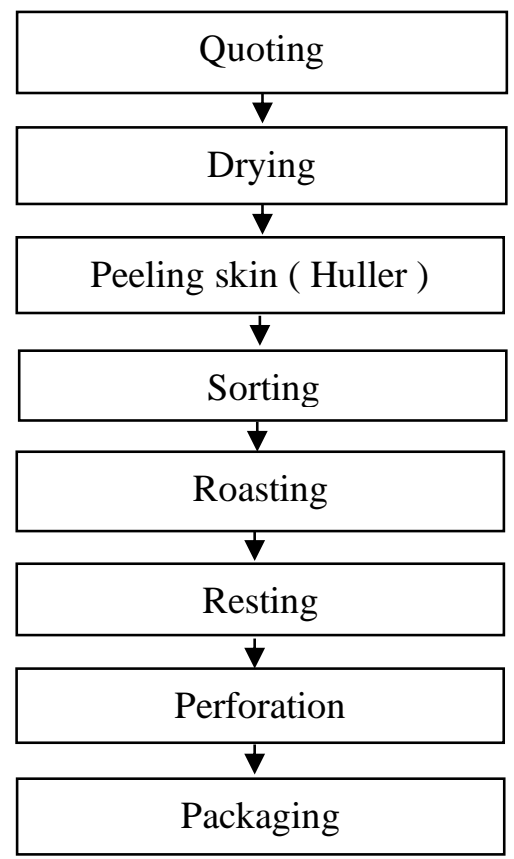

Figure 1. Stages of dry coffee processing at Small Medium Enterprises (SMEs) Tugu Juang Coffee

The picking process is a process that is not arbitrary even though it is an easy matter. In the picking process, the fruit that is picked is a coffee fruit that has been red in colour and at the time of picking, the fruit stalk is not picked or damaged because the stalk will produce fruit again [16]. The characteristics of the coffee cherries are seen from the level of maturity, namely green indicates that the coffee cherries are still young, yellow coffee cherries indicate half of the cooking, red coffee cherries indicate full ripe coffee, and black coffee beans indicate overripe Methods The initial sorting process of coffee in Small Medium Enterprises (SMEs) Tugu Juang Coffee uses the copter method (coffee fruit containing red coffee) by using water media. The hollow red coffee fruit will float to the surface of the water [17].

The drying process at Small Medium Enterprises (SMEs) Tugu Juang Coffee uses the solar drying method for 20-25 days. In principle, the drying process is an activity to remove moisture from an agricultural material which is to prevent fungal, enzyme and insect activity attacks. After the coffee cherries are harvested as soon as possible the coffee cherries are dried to avoid degrading the quality of the coffee beans. The solar dryer is a drying method using a collector that utilizes solar energy radiation more optimally so that the heat makes the coffee beans dry quickly. The drier the seeds, the better the quality because fungi and other diseases are difficult to enter with very low moisture content [18].

The process of peeling dry coffee skin is a process where dry coffee cherries are peeled to remove horn skin, fruit skin and epidermis to get clean and good quality coffee beans [19]. In this process, you can use a huller machine. The process of stripping the skin with a huller machine to produce good coffee beans in Small Medium Enterprises (SMEs) Tugu Juang Coffee is done repeatedly. At the time of inserting the first coffee beans, dry skin was still attached to the coffee 
beans and skin waste was still carried away. After that, the coffee beans return to the huller machine to make the coffee beans cleaner [20].

The sorting process is an activity to separate coffee beans based on size, bean defects, and foreign objects. To produce a good grade, the sorting process is very influential in creating the quality of the coffee taste, the more foreign objects that enter such as twigs, gravel, or skin, it will affect the taste quality. Two types of coffee defects must be separated, namely 1) Elephant Beans, 2) Odd-shaped seeds, 3) Hole-shaped seeds, 4) black seeds [21]. Elephant Beans are seeds that have no contents or one of them. a bigger side which causes the beans when roasting is easy to burn, odd-shaped seeds. It is a bean in which there is only 1 bean in the coffee fruit, this will affect the uneven roasting process when accompanied by superior beans in general [9]. But to keep producing, Small Medium Enterprises (SMEs) Tugu Juang Coffee makes coffee called lanang coffee, which is coffee that comes from a single bean. This coffee is valued more expensive than regular coffee because the sorting process of lanang coffee beans must be done painstakingly. Seed with holes It is a coffee defect caused by pest attacks, the beans that are affected by pests will taste very bitter and not dense, reducing the quality of the coffee. Blackened beans are defects of coffee due to being contaminated because they have touched the ground so that they are exposed to other substances or bacteria [22].

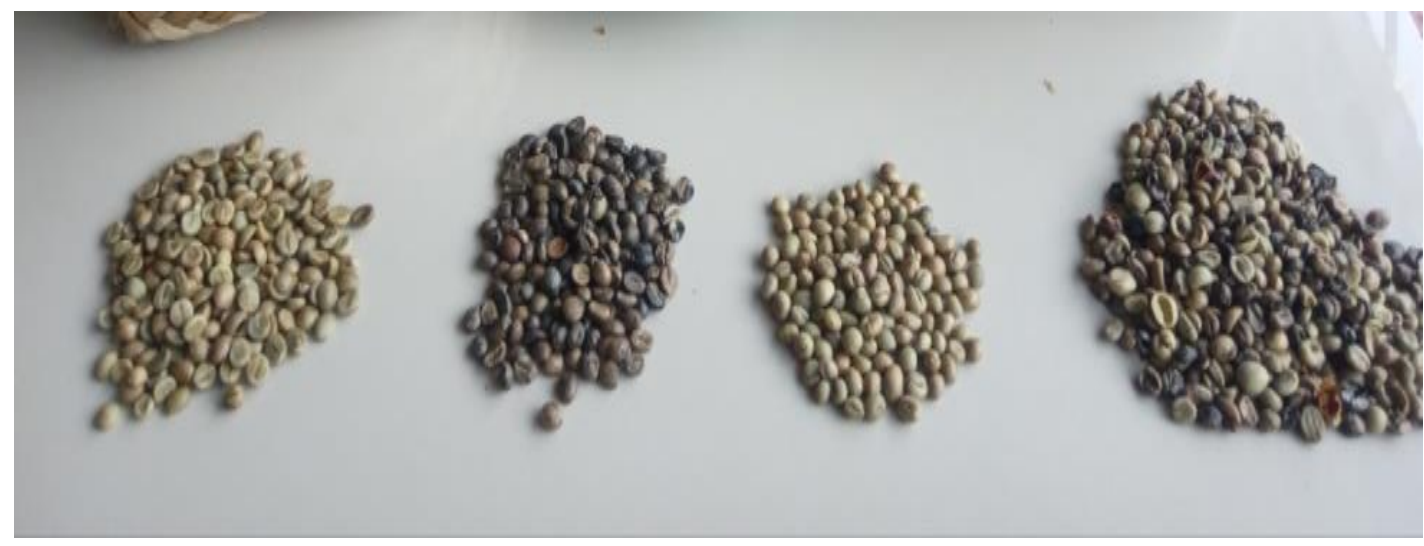

Figure 2. coffee beans intact, blackened, odd, hollow and perforated in Small Medium Enterprises (SMEs) Tugu Juang Coffee

The sorting process is carried out in 2 ways, namely the manual process and the machining process. The manual process is used to retrieve the types of coffee beans that have coffee defects and the machine is used to determine the grade. To obtain grades A, B, and C, it is done using a sorting tool, namely a grading machine, where grade A produces large coffee beans, grade $\mathrm{B}$ is medium, and grade $\mathrm{C}$ is small [23].

The roasting process is a process of roasting or frying coffee beans with hot media of a roasting machine which functions to create aroma and delicacy in coffee and reduce the water content of coffee [24]. The posting process takes between 10 and 30 minutes. During the roasting process, the coffee beans also experience significant weight loss due to the process of water evaporation. Roasting coffee at various temperatures will cause changes in the physical properties of the coffee beans due to decreased moisture content, increased brittleness and accelerated colour change [25]. There are several levels of corrosion that can be seen from the colour of the coffee beans, namely Light roast, Medium roast and Dark roast [26]. Light roast is sufficient coffee roasting, which uses a temperature of 190-195 degrees Celsius to produce a dark brown colour. Medium roast is a medium roast with a temperature of 200-205 degrees Celsius which produces a blackish-brown colour. Dark roast is coffee roasting with temperatures above 205 degrees Celsius which produces black coffee [27]. 


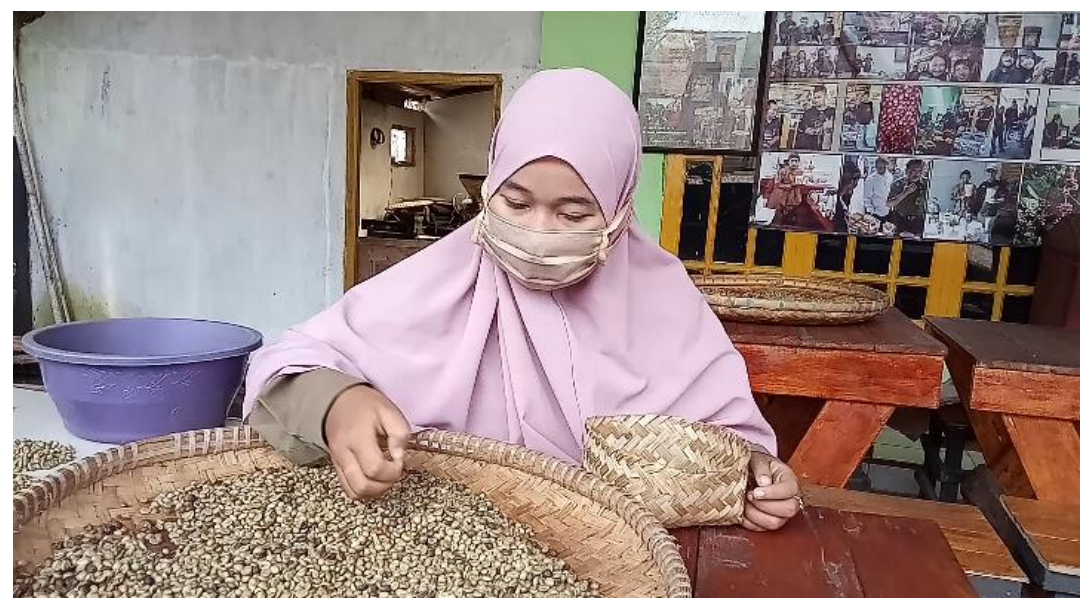

Figure 3. Sorting process manually

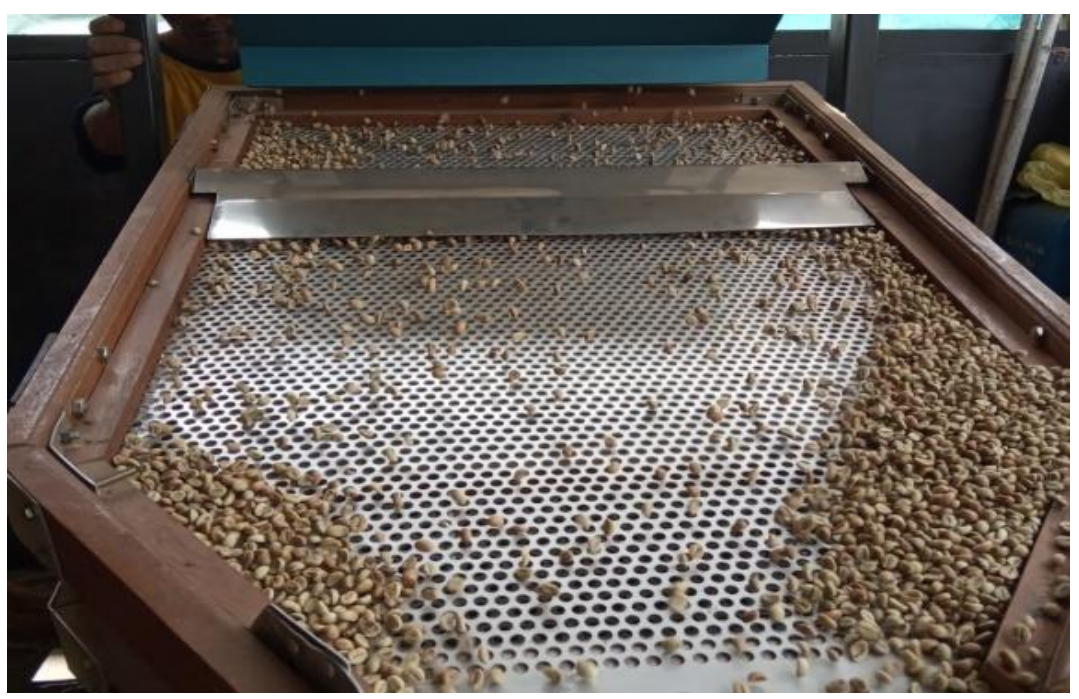

Figure 4. The sorting process uses a sorting machine

The resting process is a coffee resting process before it is processed into coffee powder [28]. the goal of resting is to reduce the carbon dioxide levels that are still left behind because it causes the coffee to tasteless delicious because it drinks it together with carbon dioxide [29]. resting is needed to allow time for the release of carbon dioxide so that the coffee flavour profile is also more optimal. The longer the setting, the better the taste is served [30]. Small Medium Enterprises (SMEs) Tugu Juang Coffee have to resting process takes around 1-14 days. The process of pulverizing coffee is the process of crushing coffee into particles which is the final process in making coffee. In the process of powdering at Small Medium Enterprises (SMEs) Tugu Juang Coffee using a grinder machine. The powdering process is carried out based on a certain size, the finer the coffee beans, the sharper the taste, because all the substances contained in coffee dissolve in water. The level of grind size is coarse (coarse), medium (medium), fine (fine), very fine (very fine) [31].

The coffee packaging process is a process of putting coffee into the packaging to maintain coffee quality, minimize damage, facilitating the distribution process and increasing the selling value of the product [32]. Small Medium Enterprises (SMEs) Tugu Juang Coffee usuage packaged in 3 types of packaging, namely 1) Standing pouch kraft papper packaging, 2) Standing pouch Kpack packaging, 3) Standing pouch packaging. Standing pouch kraft papper packaging is a type of packaging used by Small Medium Enterprises (SMEs) Tugu Juang Coffee for used in

Postharvest Handling of Coffee In Small Medium Enterprises (SMEs) Tugu Juang Coffee Pulosari Village Pemalang Regency (Sari Salsabila Rizkiyani, Yan El Rizal Unzilatirrizqi) 
packaging coffee weighing 100 grams. This package has a zipper and the outside uses kraft material and the inside uses aluminium foil. Usually used in packing arabica coffee. Standing pouch K-pack is a type of packaging used by Small Medium Enterprises (SMEs) Tugu Juang Coffee to package coffee powder with a coffee weight of 200 grams and 100 grams, this packaging is equipped with a zipper and is made of aluminium foil, usually used for packaging. robusta arabica coffee. Standing pouch (plastic) packaging made of plastic is a type of packaging used by Small Medium Enterprises (SMEs) Tugu Juang Coffee to package coffee beans that are still beans, usually used to pack coffee beans weighing $1 \mathrm{~kg}$.

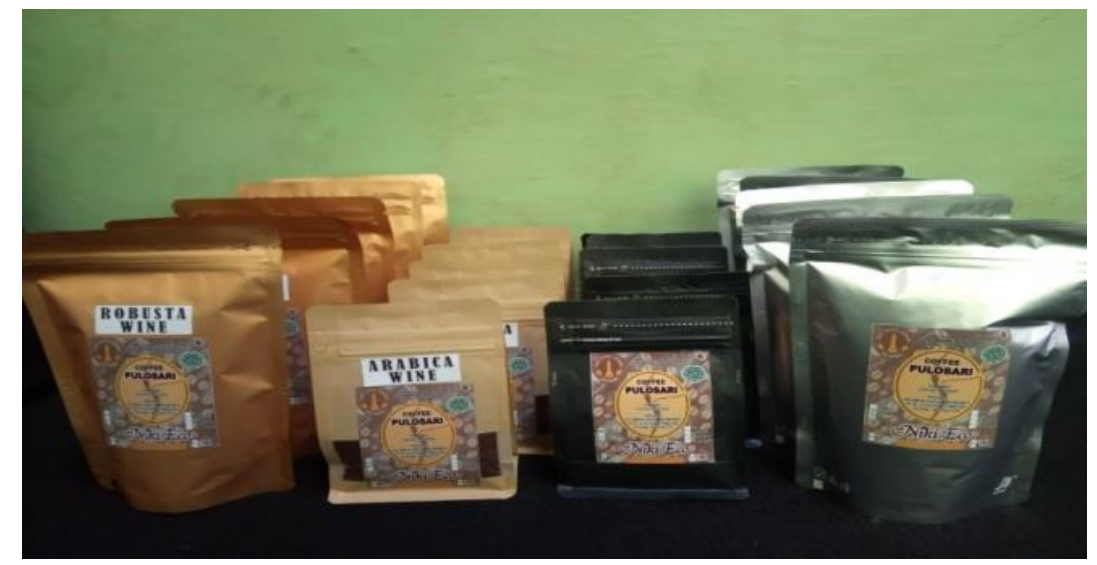

Figure 5. Examples of types of packaging at Small Medium Enterprises (SMEs) Tugu Juang Coffee

So that coffee is always maintained after the coffee is packed with a standing pouch and closed with a zipper, the coffee is sealed again with a sealer machine, with the aim that the coffee if distributed will not open because it is completely closed and so that the aroma of coffee will be maintained [33]. Labeling in the packaging of Small Medium Enterprises (SMEs) Tugu Juang Coffee also takes into account the labelling of food products which at least must pay attention to 1) Product name, 2) List of ingredients used, 3) Net weight, 4) Name and address of the producer, 5) Halal information, and 5) The date of the month and year of expiration

\subsection{Water Content}

The water content of coffee beans in Small Medium Enterprises (SMEs) Tugu Juang Coffee before drying reaches $25-30 \%$ and after drying it produces a maximum moisture content of $12 \%$. The best water content of coffee is a maximum of $12.5 \%$ [34]. Coffee that has met the requirements in coffee water content allows the number of contaminated bacteria and pests to be very small because there is no room for bacteria to develop with small moisture content [35]. Small Medium Enterprises (SMEs) Tugu Juang Coffee determines the water content using a moisture measuring device, namely the Grain Moisture Meter (MC-7828 G), and biting the coffee beans is also carried out, if the coffee beans when bitten do not experience shrinkage or use, the coffee bean moisture content is certainly low. 


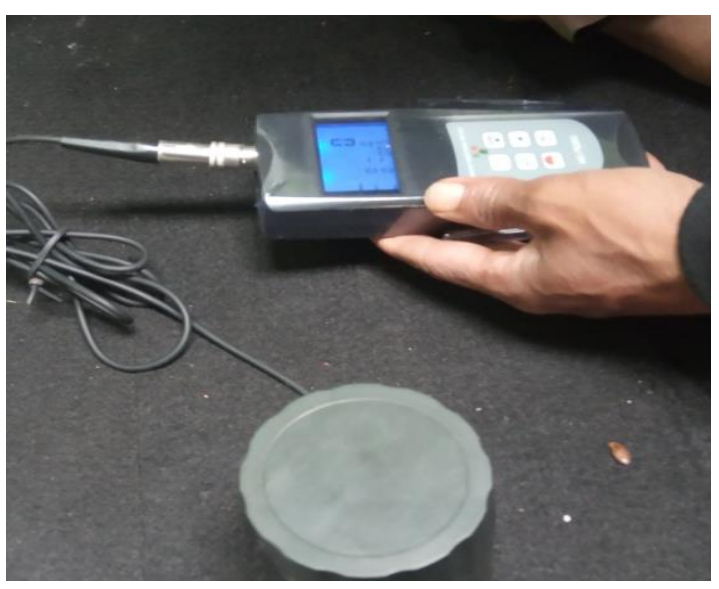

Figur 6. Grain Moisture Meter (MC-7828 G) in Small Medium Enterprises (SMEs) Tugu Juang Coffee

\subsection{Coffee storage and moisture storage process}

The coffee warehousing process at Small Medium Enterprises (SMEs) Tugu Juang Coffee does not have a special place for storing coffee beans due to the lack of coffee locations that coincide with the house of the head of the farmer group. The warehousing of coffee beans at Tugu Juang UKM is carried out by placing the coffee beans on a wooden base and placing them next to the wall and on the side given a cardboard base so that they do not come into direct contact with the wall in order not to be contaminated with bacteria inside the wall. 5 important things need to be considered in packaging and warehousing, namely 1) Labeling the sacks to show the type of quality and the identity of the producers, (2) The sacks are clean and free of foreign odours, (3) The piles are arranged using a wooden base with a wall limit of $50 \mathrm{~cm}$ and a maximum height of the sack pile is $150 \mathrm{~cm}$ from the roof of the warehouse, (4) The condition of the beans is then always checked during storage to find out how water content and whether there are disturbing organisms that can damage the coffee beans, (5) Always clean the warehouse area and keep $70 \%$ humidity and adequate ventilation is required [36]. The process of warehousing and humidity of the warehouse in Small Medium Enterprises (SMEs) Tugu Juang Coffee maintains sack cleaning, ventilation and labelling.

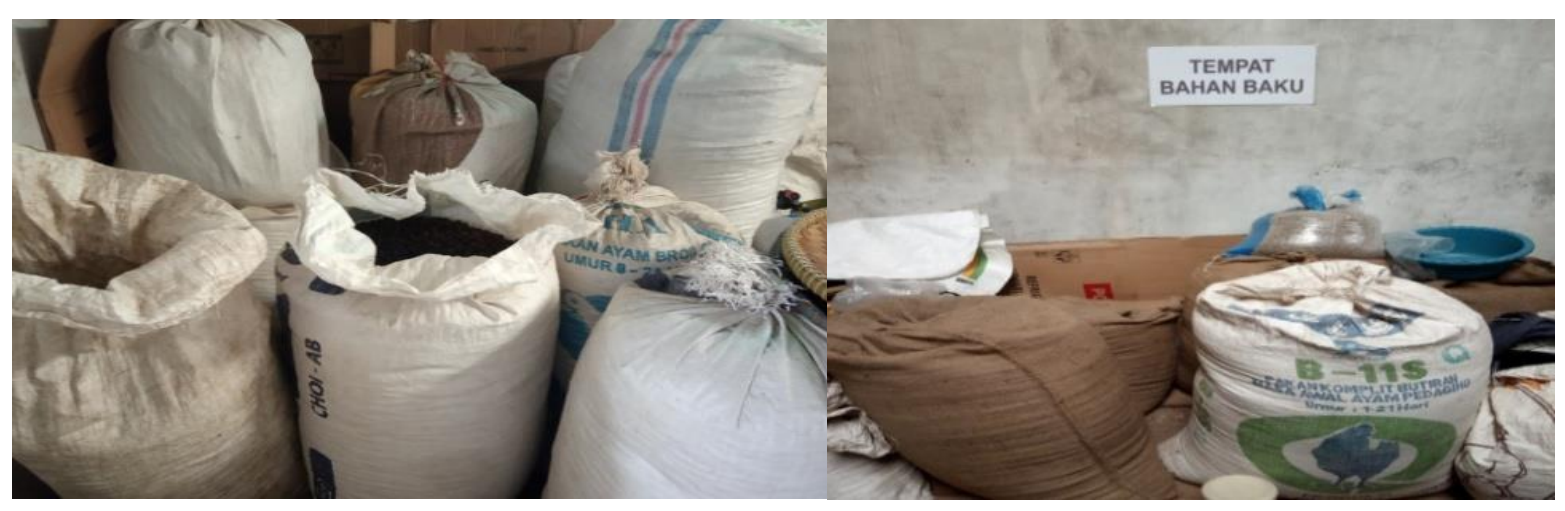

Figure 7. The warehousing process in Small Medium Enterprises (SMEs) Tugu Juang Coffee 


\section{Conclusion}

Small Medium Enterprises (SMEs) Tugu Juang Coffee cultivates robusta and arabica coffee. The processing of coffee at Small Medium Enterprises (SMEs) Tugu Juang Coffee is by processing it dry (natural). The water content of coffee beans according to SNI is $12.5 \%$ and the height of Arabica coffee is 700-1700 masl and robusta is less than 700 masl. The process of storing coffee pays attention to sack cleaning, ventilation and labelling.

\section{Acknowledgement}

Thank you to Mr. Muhamad Hasdar who has guided and helped finalize this article for publication and Mr Hasan as owner Small Medium Enterprises (SMEs) Tugu Juang Coffee place this research.

\section{References}

[1] W. B. Sunarharum, S. S. Yuwono, N. B. S. W. Pangestu, dan H. Nadhiroh, "Physical and sensory quality of Java Arabica green coffee beans," IOP Conf. Ser. Earth Environ. Sci., vol. 131, no. 1, 2018.

[2] S. D. W. Prajanti, S. E. Pramono, dan F. Adzmin, "Factors Influencing Indonesia Coffee Exports Volume," Int. Conf. Res. Acad. Community Serv. (ICRACOS 2019), vol. 390, no. Icracos 2019, pp. 41-45, 2020.

[3] D. R. Seninde dan E. Chambers, "Coffee flavor: A review," Beverages, vol. 6, no. 3, pp. $1-25,2020$.

[4] N. Rosiana, R. Nurmalina, R. Winandi, dan A. Rifin, "Dynamic of Indonesian robusta coffee competition among major competitor," J. Tanam. Ind. dan Penyegar, vol. 5, no. 1, pp. 1-10, 2018.

[5] B. R. Handayani, "Coffee and Its Flavor," J. Ilm. Rekayasa Pertan. dan Biosist., vol. 4, no. 1, pp. 222-227, 2016.

[6] P. Ghosh dan N. Venkatachalapathy, "Processing and Drying of Coffee - A review," Int. J. Eng. Res. Technol., vol. 3, no. 12, pp. 784-794, 2014.

[7] C. J. Pimenta, C. L. Angélico, dan S. M. Chalfoun, "Challengs in coffee quality: Cultural, chemical and microbiological aspects Desafios na qualidade de café: Aspectos cultural, químico e microbiológico," Ciência e Agrotecnologia, vol. 42, no. 4, pp. 337-349, 2018.

[8] P. Siagian, E. Y. Setyawan, T. Gultom, F. H. Napitupulu, dan H. Ambarita, "A field survey on coffee beans drying methods of Indonesian small holder farmers," IOP Conf. Ser. Mater. Sci. Eng., vol. 237, no. 1, pp. 1-7, 2017.

[9] R. K. Kipkorir, P. Muliro, dan S. Muhoho, "Effects of coffee processing technologies on physico-chemical properties and sensory qualities of coffee," African J. Food Sci., vol. 9, no. 4, pp. 230-236, 2015.

[10] M. Hasdar, A. Bashar, dan W. Wadli, "Penumbuhan Jiwa Wirausaha Siswa SMK Ma'arif NU 01 Wanasari Melalui Pelatihan Pengolahan Limbah Air Kelapa," Pambudi, vol. 3, no. 1, pp. 29-37, 2019.

[11] M. D. C. Tongco, "Purposive sampling as a tool for informant selection. Ethnobotany research and applications," Ethnobot. Res. Appl., vol. 5, pp. 147-158, 2007.

[12] P. Poltronieri dan F. Rossi, "Challenges in Specialty Coffee Processing and Quality Assurance," Challenges, vol. 7, no. 2, pp. 1-22, 2016.

[13] F. De Bruyn et al., "Exploring the Impacts of Postharvest Processing on the Microbiota and," Appl. Environ. Microbiol., vol. 83, no. 1, pp. 1-16, 2017.

[14] Y. Pham, K. Reardon-Smith, S. Mushtaq, dan G. Cockfield, "The impact of climate change and variability on coffee production: a systematic review," Clim. Change, vol. 156,

Postharvest Handling of Coffee In Small Medium Enterprises (SMEs) Tugu Juang Coffee Pulosari Village Pemalang Regency (Sari Salsabila Rizkiyani, Yan El Rizal Unzilatirrizqi) 
no. 4, pp. 609-630, 2019.

[15] P. Läderach et al., "Systematic agronomic farm management for improved coffee quality," F. Crop. Res., vol. 120, no. 3, pp. 321-329, 2011.

[16] R. Hamdani Harahap, Humaizi, dan I. Muda, "Sustainable management of coffee farms (case in Karo Regency, North Sumatera Indonesia)," Int. J. Civ. Eng. Technol., vol. 9, no. 11, pp. 2721-2731, 2018.

[17] N. Kuswardhani, M. Misbahudin, dan B. H. Purnomo, "Physical quality improvement of coffee Robusta (Coffee robusta Lindl) in Argopuro Mountain, Jember," IOP Conf. Ser. Earth Environ. Sci., vol. 250, no. 1, 2019.

[18] S. Suherman, H. Widuri, S. Patricia, E. E. Susanto, dan R. J. Sutrisna, "Energy analysis of a hybrid solar dryer for drying coffee beans," Int. J. Renew. Energy Dev., vol. 9, no. 1, pp. 131-139, 2020.

[19] S. A. Adeleke, O. J. Olukunle, J. A. Olaniran, dan Famuyiwa B.S., "Design Of A SmallScale Hulling Machine For Improved Wet-Processed Coffee.," Int. J. Sci. Technol. Res., vol. 06, no. 08, pp. 391-397, 2017.

[20] C. S. Valdiney et al., "Drying of hulled naturally processed coffee with high moisture content and its impacts on quality," African J. Agric. Res., vol. 11, no. 31, pp. 2903-2911, 2016.

[21] D. Nugroho, P. Basunanda, dan S. Mw, "Physical Bean Quality of Arabica Coffee (Coffea Arabica) Cultivated at High and Medium Altitude," Pelita Perkeb. (a Coffee Cocoa Res. Journal), vol. 32, no. 3, pp. 151-161, 2016.

[22] S. J. Zhang et al., "Following coffee production from cherries to cup: Microbiological and metabolomic analysis of wet processing of Coffea arabica.," Appl. Environ. Microbiol., vol. 85, no. 6, pp. 1-22, 2019.

[23] S. I. Mussatto, E. M. S. Machado, S. Martins, dan J. A. Teixeira, "Production, Composition, and Application of Coffee and Its Industrial Residues," Food Bioprocess Technol., vol. 4, no. 5, pp. 661-672, 2011.

[24] J. A. Vignoli, M. C. Viegas, D. G. Bassoli, dan M. de T. Benassi, "Roasting process affects differently the bioactive compounds and the antioxidant activity of arabica and robusta coffees," Food Res. Int., vol. 61, pp. 279-285, 2014.

[25] N. A. Abdul Majid, M. F. Edzuan Abdullah, dan A. Diana, "A Review of Quality Coffee Roasting Degree Evaluation,” J. Appl. Sci. Agric., vol. 10, no. 7, pp. 18-23, 2015.

[26] C. Somporn, A. Kamtuo, P. Theerakulpisut, dan S. Siriamornpun, "Effects of roasting degree on radical scavenging activity, phenolics and volatile compounds of Arabica coffee beans (Coffea arabica L. cv. Catimor)," Int. J. Food Sci. Technol., vol. 46, no. 11, pp. 2287-2296, 2011.

[27] M. R. Jokanović, N. R. Džinić, B. R. Cvetković, S. Grujić, dan B. Odžaković, "Changes of physical properties of coffee beans during roasting," Acta Period. Technol., vol. 43, no. 1, pp. 21-31, 2012.

[28] C. F. Ross, K. Pecka, dan K. Weller, "Effect of storage conditions on the sensory quality of ground arabica coffee," J. Food Qual., vol. 29, no. 6, pp. 596-606, 2006.

[29] N. Salmaa Dwiranti, A. Ardiansyah, dan N. Asiah, "Sensory Attributes of Cold Brew Coffee Products at Various Resting Time After Roasting Process," Pelita Perkeb. (a Coffee Cocoa Res. Journal), vol. 35, no. 1, pp. 42-50, 2019.

[30] D. R. Seninde dan E. C. Iv, "Co ff ee Flavor: A Review," hal. 28-33, 2020.

[31] T. Klingel, J. I. Kremer, V. Gottstein, T. R. De Rezende, S. Schwarz, dan D. W. Lachenmeier, "A review of coffee by-products including leaf, flower, cherry, husk, silver skin, and spent grounds as novel foods within the European Union," Foods, vol. 9, no. 5, 2020.

[32] K. Marsh dan B. Bugusu, "Food packaging - Roles, materials, and environmental issues: Scientific status summary," J. Food Sci., vol. 72, no. 3, 2007.

[33] U. L. Opara dan A. Mditshwa, "A review on the role of packaging in securing food system: Adding value to food products and reducing losses and waste," African J. Agric. Res., vol.

Postharvest Handling of Coffee In Small Medium Enterprises (SMEs) Tugu Juang Coffee Pulosari Village Pemalang Regency (Sari Salsabila Rizkiyani, Yan El Rizal Unzilatirrizqi) 
8, no. 22, pp. 2621-2630, 2013.

[34] A. Adnan, D. von Hörsten, E. Pawelzik, dan and D. Mörlein, "Rapid Prediction of Moisture Content in Intact Green Coffee Beans Using Near Infrared Spectroscopy," Foods, vol. 6, no. 5, pp. 1-11, 2017.

[35] P. Pittia, M. C. Nicoli, dan G. Sacchetti, "Effect of moisture and water activity on textural properties of raw and roasted coffee beans," J. Texture Stud., vol. 38, no. 1, pp. 116-134, 2007.

[36] P. Bucheli, I. Meyer, A. Pittet, G. Vuataz, dan R. Viani, "Industrial Storage of Green Robusta Coffee under Tropical Conditions and Its Impact on Raw Material Quality and Ochratoxin A Content," J. Agric. Food Chem., vol. 46, no. 11, pp. 4507-4511, 1998. 